\title{
EFFECTS OF OVARIECTOMY AND/OR ADRENALECTOMY ON VIABILITY OF BLASTOCYSTS IN RATS
}

\author{
A. P. LABHSETWAR* \\ Pharmaceuticals Division, Imperial Chemical Industries Limited, \\ Alderley Park, Macclesfield, Cheshire
}

(Received 21st December 1970)

\begin{abstract}
Summary. Ovariectomy of rats on Day 3 or Day 4 of pregnancy and autopsy 5 to 6 days later, with no replacement therapy in the intervening period, resulted in an average recovery of five to six blastocysts/rat. When adrenalectomy was coupled with ovariectomy, the blastocyst recovery was markedly reduced. Administration of progesterone to such rats improved the blastocyst yield. When blastocysts from rats subjected to ovariectomy or ovariectomy and adrenalectomy were transferred to pseudopregnant hosts, the proportion which developed into viable foetuses was markedly lower than the proportion developing from blastocysts harvested from intact rats or ovariectomized rats treated with progesterone. Thus, ovariectomy alone or coupled with adrenalectomy appears to exert deleterious effects on both the number and viability of blastocysts in rats.
\end{abstract}

\section{INTRODUCTION}

Ovariectomy of rats and mice in early pregnancy, followed by daily treatment with progesterone, results in delayed implantation of the blastocysts (see Enders, 1963, 1967; McLaren, 1969). This procedure has often been used as an experimental model for the study of blastocyst-uterine relationships. In such studies, however, the rôle of the adrenal gland in influencing blastocyst survival has not been adequately evaluated. In fact, the fate of blastocysts in rats following ovariectomy is disputed. While Meyer and his co-workers failed to obtain implantation when oestrogen-progesterone treatment was withheld for approximately a week following ovariectomy of pregnant rats (Cochrane \& Meyer, 1957; Nutting \& Meyer, 1963), others (Canivenc \& Laffargue, 1957; Buchanan, 1969) did obtain implantation of blastocysts following comparable treatment. Dickmann (1968) transferred blastocysts to the uteri of rats bilaterally spayed 30 days earlier and found $34 \%$ of them viable as judged by their capacity to implant following retransfer to pseudopregnant recipients. Smithberg \& Runner (1960), using immature mice and Weitlauf \& Greenwald (1968), using adult mice, reported maintenance of blastocysts in a viable state for at least 4 weeks in the absence of ovarian progesterone. The latter authors

* Present address: Worcester Foundation for Experimental Biology, Shrewsbury, Mass. 01545, U.S.A. 
have concluded that mouse blastocysts require no progesterone for survival during delayed implantation.

The recovery of healthy looking blastocysts from pregnant rats ovariectomized on Day 3 of pregnancy and left untreated for 6 days, prompted an investigation into the possible effects of ovariectomy combined with adrenalectomy on the viability of blastocysts.

\section{MATERIALS AND METHODS}

Sexually mature female rats of a Wistar-derived strain, randomly bred for several generations under specific pathogen-free conditions, were used in this study. The rats were exposed to $14 \mathrm{hr}$ light $/ 10 \mathrm{hr}$ dark per day and allowed free access to food and tap water. They were housed in a temperature-controlled room maintained at $71^{\circ} \mathrm{F}$. Vaginal smears were taken daily throughout the experimental period.

The first part of the study was concerned with the persistence of blastocysts in the absence of the ovaries and/or the adrenals. As the study progressed, it became apparent that the morphological appearance of blastocysts under the microscope is not an adequate criterion of their viability. The second and third parts of the study were designed to assess blastocyst viability.

Rats were caged with males on the night of pro-oestrus and if the vaginal smears then contained spermatozoa, the following day was taken as Day 1 of pregnancy. On the morning of Day 3 or 4 , rats were bilaterally spayed under ether anaesthesia. The ovarian bursa was slit and the ovary removed with a minimum of damage to the Fallopian tubes. No suture was used. The resulting haemorrhage, which was usually slight, appeared to be of no consequence to the survival of blastocysts. In some groups, bilateral adrenalectomy was performed at the same time through the same incision. Such rats were, thereafter, given sodium chloride $(0.9 \%)$ in their drinking water. When required, progesterone (Searle Co. or BDH) was injected subcutaneously daily (2 $\mathrm{mg}$ or $4 \mathrm{mg}$ in oil) on the day of operation and continued until the day before autopsy. The steroid powder was dissolved in arachis oil by heating the mixture in a water bath. All rats were killed on Days 8 to 10 of pregnancy, at which time uteri were flushed with phosphate buffer $(\mathrm{pH} \mathrm{7.4)}$ and the number of blastocysts determined under a microscope. At a later date, the entire experiment was repeated (Groups B in Table 1). In an additional group of rats (controls), a sham operation was performed. This involved slitting the ovarian bursa on the morning of Day 3 or 4 of pregnancy and manipulating the adrenals in a manner similar to that preceding adrenalectomy. The controls were either killed on the morning of Day 5 and the blastocyst yield determined or left until Day 14 of pregnancy when the number and size of implants was determined. Completeness of ovariectomy in this experiment was checked by evaluating the vaginal smears daily and also from the uterine weight at autopsy.

In the second part of the study, the viability of blastocysts was tested (Canivenc \& Laffargue, 1957; Meyer \& Cochrane, 1962) according to the procedure shown in Text-fig. 1. Rats were ovariectomized and/or adrenalectomized on 
TABLE 1

EFFECT OF ADRENALECTOMY AND PROGESTERONE-TREATMENT ON BLASTOCYST RECOVERY IN BILATERIALLY SPAYED RATS

\begin{tabular}{|c|c|c|c|c|c|c|c|c|}
\hline Group & $\begin{array}{c}\text { Day } \\
\text { ovaries } \\
\text { removed }\end{array}$ & $\begin{array}{c}\text { Day } \\
\text { adrenals } \\
\text { removed }\end{array}$ & $\begin{array}{c}\text { Progesterone } \\
\text { s.c. } \\
\text { (dose/rat) }\end{array}$ & $\begin{array}{l}\text { Day of } \\
\text { autopsy }\end{array}$ & $\begin{array}{r}\text { Rats } \\
\text { blaste } \\
\text { rats in } \\
\text { (O }\end{array}$ & $\begin{array}{l}\text { with } \\
\text { oysts/ } \\
\text { group } \\
\text { o) }\end{array}$ & $\begin{array}{c}\text { Mean } \\
\text { no. of } \\
\text { blastocysts } \\
\text { (Mean } \pm S . E .)\end{array}$ & $\begin{array}{c}\text { Uterine } \\
\text { weight in } m g \\
\text { (Mean士 } \\
\text { S.E. })^{-}\end{array}$ \\
\hline $\begin{array}{c}1 \mathrm{~A} \\
1 \mathrm{~B} \\
2 \mathrm{~A} \\
2 \mathrm{~B} \\
3 \mathrm{~A} \\
3 \mathrm{~B} \\
4 \mathrm{~A} \\
4 \mathrm{~B} \\
5 \mathrm{~A}^{\mathrm{f}} \\
5 \mathrm{~B} \\
6 \mathrm{~A}^{\mathrm{f}} \\
6 \mathrm{~B} \\
7 \\
8 \\
9 \\
10 \\
11 \\
12^{\mathrm{h}}\end{array}$ & $\begin{array}{l}3 \\
3 \\
3 \\
3 \\
3 \\
3 \\
3 \\
3 \\
4 \\
4 \\
4 \\
4 \\
4 \\
4 \\
\frac{(3)^{1}}{(3)^{1}} \\
3\end{array}$ & $\begin{array}{l}\bar{Z} \\
3 \\
3 \\
3 \\
3 \\
= \\
= \\
\overline{-} \\
4 \\
4 \\
4 \\
3 \\
(3)^{i} \\
(3)^{1}\end{array}$ & $\begin{array}{c}\bar{Z} \\
\overline{-} \\
2 \mathrm{mg} / \mathrm{day} \\
4 \mathrm{mg} / \mathrm{day} \\
2 \mathrm{mg} / \mathrm{day} \\
4 \mathrm{mg} / \mathrm{day} \\
\overline{-} \\
\overline{-} \\
4 \mathrm{mg} / \mathrm{day} \\
4 \mathrm{mg} / \mathrm{day} \\
\overline{-} \\
4 \mathrm{mg} / \text { day }\end{array}$ & $\begin{array}{l}8 \text { to } 10 \\
10 \\
8 \text { to } 10 \\
10 \\
10 \\
10 \\
8 \text { to } 10 \\
10 \\
10 \\
10 \\
10 \\
10 \\
10 \\
10 \\
9 \\
5 \\
14 \\
14\end{array}$ & $\begin{array}{l}6 / 8 \\
4 / 5 \\
2 / 12^{\mathrm{c}} \\
2 / 5 \\
5 / 5 \\
4 / 5 \\
8 / 8 \\
4 / 5 \\
8 / 8 \\
5 / 5 \\
7 / 8^{\mathrm{c}} \\
5 / 5 \\
4 / 5 \\
5 / 5 \\
6 / 6^{\mathrm{z}} \\
6 / 6 \\
6 / 6^{\mathbf{z}} \\
4 / 5^{\mathrm{z}}\end{array}$ & $\begin{array}{l}(75) \\
(80) \\
(17) \\
(40) \\
(100) \\
(80) \\
(100) \\
(80) \\
(100) \\
(100) \\
(88) \\
(100) \\
(80) \\
(100) \\
(100) \\
(100) \\
(100) \\
(80)\end{array}$ & $\begin{array}{c}5 \cdot 3 \pm 1 \cdot 4 \\
3 \cdot 3 \pm 1 \cdot 1 \\
1 \cdot 5^{\mathrm{b}} \\
1 \cdot 0 \\
4 \cdot 2 \pm 1 \cdot 0 \\
5 \cdot 0 \pm 1 \cdot 1 \\
6 \cdot 1 \pm 0 \cdot 7 \\
8 \cdot 3 \pm 0 \cdot 5 \\
5 \cdot 8 \pm 0 \cdot 7 \\
5 \cdot 6 \pm 1 \cdot 1 \\
3 \cdot 1 \pm 0 \cdot 9^{d *} \\
3 \cdot 2 \pm 0 \cdot 8 \\
8 \cdot 3 \pm 0 \cdot 9 \\
7 \cdot 4 \pm 0 \cdot 5 \\
11 \cdot 0^{\mathrm{z}} \pm 0 \cdot 3 \\
9 \cdot 3 \pm 0 \cdot 5 \\
10 \cdot 8^{\mathrm{z}} \pm 0 \cdot 9 \\
6.8^{\mathbb{8}} \pm 2 \cdot 0\end{array}$ & $\begin{array}{c}175 \pm 11 \\
140 \pm 7 \\
184 \pm 8 \\
146 \pm 13 \\
217 \pm 7 * \\
204 \pm 13 \\
215 \pm 9 * \\
231 \pm 12 \\
175 \pm 7 \\
147 \pm 14 \\
161 \pm 8 \\
145 \pm 5 \\
202 \pm 14 \\
181 \pm 13 \\
383 \pm 22 \\
=\end{array}$ \\
\hline
\end{tabular}

* $P<0.05$ when compared with Group $1 \mathrm{~A}$.

a Mean is based on animals from which blastocysts were recovered.

- All blastocysts were undergoing degeneration.

c Out of a total of thirteen animals, one died.

d $P<0.05$ when compared with Group 5A.

- One animal died.

' One animal in each group was discarded.

Implants.

h These rats received a single injection of oestrone $(1 \mu \mathrm{g})$ on Day 4.

i All sham operations performed on Day 3.

the morning of Day 4 of pregnancy and left untreated until Day 8 when a laparotomy was performed. Rats showing no visible implantation sites were injected subcutaneously once daily with progesterone in oil $(10 \mathrm{mg} /$ day $)$ from Days 8 to 20 inclusive. On Day 11 of pregnancy, i.e. on the 4th day of progesterone injection, a single subcutaneous injection of oestrone $(1 \mu \mathrm{g} / \mathrm{rat})$ was given to induce implantation of any blastocysts which might have been present. One day following the last day of progesterone injection (i.e. on Day 21), the

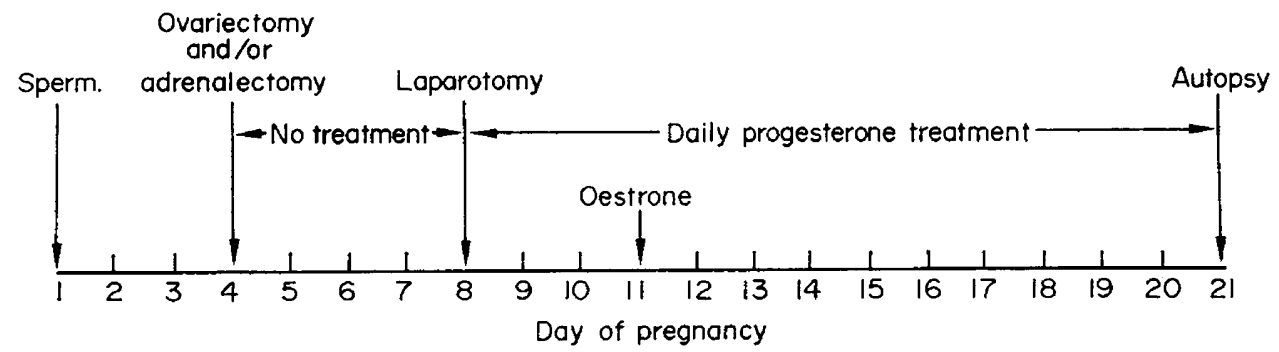

TexT-FIG. 1. Protocol for testing viability of blastocysts in ovariectomized and/or adrenalectomized rats. 
rats were killed and the number and size of the implants determined. A few implantation sites were saved for histological study. Since the oestrogen surge in rats occurs on Day 4 of pregnancy (Shelesnyak, 1960; Shaikh \& Abraham, 1969), the day of oestrone injection (Day 11) could be taken to correspond to Day 4 of normal pregnancy. On this basis, Day 21 would correspond to Day 14 of normal pregnancy. Intact rats were, therefore, killed on Day 14 of pregnancy and the number and size of the implants were similarly determined. An additional group of rats was bilaterally ovariectomized on the morning of Day 4 and injected daily with $4 \mathrm{mg}$ progesterone until Day 14. A single injection of oestrone $(1 \mu \mathrm{g})$ was given on the morning of Day 4 . Autopsy was performed on Day 14 (Treatment-group 4, Table 2).

TABLE 2

EFFECTS OF ADRENALECTOMY ON VIABILITY OF BLASTOCYSTS IN THE OVARIEGTOMIZED PREGNANT RATS

\begin{tabular}{|c|c|c|c|c|c|c|}
\hline \multirow{2}{*}{$\begin{array}{l}\text { Treatment- } \\
\text { group }\end{array}$} & \multirow[t]{2}{*}{ Treatment } & \multicolumn{2}{|c|}{$\begin{array}{c}\text { Body weight }(g) \\
(\text { Mean } \pm \text { S.E. })\end{array}$} & \multirow{2}{*}{$\begin{array}{c}\text { No. of rats with } \\
\text { implant sites } \\
\text { at autopsy/ } \\
\text { no. treated } \dagger\end{array}$} & \multirow{2}{*}{$\begin{array}{c}\text { No. of implants/ } \\
\text { pregnant rat } \\
(\text { Mean } \pm \text { S.E. })\end{array}$} & \multirow{2}{*}{$\begin{array}{c}\text { Size of } \\
\text { implants } \\
(\mathrm{mm}) \\
(\text { Mean } \pm \text { S.E. })\end{array}$} \\
\hline & & Initial & Final & & & \\
\hline 1 & $\begin{array}{l}\text { Ovariectomy } \\
\text { on Day } 4\end{array}$ & $214 \pm 2$ & $247 \pm 4$ & $7 / 8$ & $7 \cdot 7 \pm 0.92$ & $7 \cdot 79 \pm 0 \cdot 41$ \\
\hline 2 & $\begin{array}{l}\text { Ovariectomy+ } \\
\text { adrenalectomy }\end{array}$ & $209 \pm 4$ & $221 \pm 10^{*}$ & $7 / 8$ & $4 \cdot 0 \pm 0 \cdot 87$ & $5 \cdot 24 \pm 0 \cdot 38^{* * *}$ \\
\hline 3 & $\begin{array}{l}\text { Intact controls } \\
\text { (sham operation } \\
\text { on Day } 3 \text { and } \\
\text { killed on Day } \\
\text { 14) }\end{array}$ & $208 \pm 7$ & $238 \pm 9$ & $6 / 6$ & $10 \cdot 8 \pm 0 \cdot 87$ & $8 \cdot 53 \pm 0 \cdot 17$ \\
\hline 4 & $\begin{array}{l}\text { Controlł (ovari- } \\
\text { ectomized on } \\
\text { Day } 4 \text { and killed } \\
\text { on Day 14) }\end{array}$ & $220 \pm 7$ & $241 \pm 5$ & $5 / 5$ & $7 \cdot 6 \pm 1 \cdot 96$ & $7 \cdot 34 \pm 0 \cdot 28$ \\
\hline
\end{tabular}

$* P<0.02 ; * * * P<0.001$.

$\dagger$ These are the rats which had no implant sites at laparotomy on Day 8.

$\ddagger$ These rats received $4 \mathrm{mg}$ progesterone/rat (s.c.) from Days 4 to 13 inclusive and a single injection of $1 \mu \mathrm{g}$ oestrone on the morning of Day 4 .

In the last part of the study, the technique of blastocyst transfer was used (Banik \& Ketchel, 1965). The recipients were all rats made pseudopregnant by caging with vasectomized males (Day 0 ). Blastocysts were transferred to them on the morning of Day 5 and they were killed on Day 20, when the number and viability of the foetuses was determined.

Four different groups of donor rats were used:

\section{Donor-group 1}

Blastocysts obtained from untreated rats on Day 5 of pregnancy (Day $1=$ presence of spermatozoa in vaginal smear) were transferred to Day-5 pseudopregnant recipients. Vaginal smears were taken daily throughout the experimental period. 
Donor-group 2

Pregnant rats were ovariectomized on the morning of Day 3 or 4 and left untreated until Day 8. On this day, blastocysts were recovered and transferred.

\section{Donor-group 3}

Blastocysts obtained from rats ovariectomized and adrenalectomized on the morning of Day 3 or 4 and left untreated until Days 8 to 10 of pregnancy were transferred to pseudopregnant recipients.

\section{Donor-group 4}

Pregnant rats were ovariectomized on the morning of Day 3 and injected subcutaneously with progesterone in oil $(4 \mathrm{mg} / \mathrm{rat} / \mathrm{day})$, from Days 3 to 7 inclusive. Blastocysts recovered on Day 8 were transferred to pseudopregnant recipients.

\section{RESULTS}

\section{Discarded rats}

Certain rats were removed from the experimental groups. Two rats from Group 1 and one rat each from Groups 5 and 6 were discarded (Table 1) since they showed cornified smears on Day 7 of pregnancy. When an ovarian site was examined histologically in one rat, it showed a remnant of ovarian tissue which contained vesicular follicles but no corpora lutea. The uterine weight in all of these rats was in the same range as that for intact rats (i.e. between 280 and $400 \mathrm{mg}$ ), indicating that ovariectomy was incomplete in these rats. One rat from Group 4A (Table 1) was also rejected since it had implantation sites at autopsy. These rats are not included in the totals given in Table 1. None of the sixteen rats used for testing viability (Treatment-groups 1 and 2, Table 2), had to be discarded since no implantation sites were found at laparotomy on Day 11 (Text-fig. 1).

\section{Effects of ovariectomy}

The number of blastocysts recovered from rats ovariectomized on the morning of Day 3 (Group 1, Table 1) or 4 (Group 5) and left untreated until autopsy on Days 8 to 10 was significantly below the number recovered from the rats subjected to sham-operation on Day 3 and killed on Day 5 (Group 10). The blastocyst yield was also significantly below the number of implant sites present on Day 14 of pregnancy following sham surgery on the morning of Day 3 (Group 11) or the normal complement of tubal ova recovered on the morning of oestrus in cycling rats (mean + S.E.; $11 \cdot 0+0 \cdot 6, \mathrm{n}=9$ ).

\section{Effect of adrenalectomy}

When adrenalectomy was combined with ovariectomy (Groups 2 and 6), there was a significant reduction in the number of blastocysts recovered (Table 1) and many blastocysts appeared degenerate. When such rats received a daily injection of progesterone from the day of operation (Groups 3 and 8), all of them had blastocysts at autopsy 6 to 7 days later. The number of blastocysts 
was not significantly different from that recovered from the bilaterally spayed rats receiving no treatment (Group 1, Table 1) or spayed rats receiving daily injections of progesterone (Group 4, Table 1). All the blastocysts appeared healthy. As expected from earlier studies (Labhsetwar, 1969), progesterone treatment had a uterotrophic effect (Groups 3 and 4, Table 1).

When rats were subjected to ovariectomy and adrenalectomy on Day 4 of pregnancy (Group 6) instead of Day 3, there was again a significant reduction in the number of blastocysts recovered when compared to rats subjected to ovariectomy alone on Day 4 (Group 5). This reduction in blastocyst yield, although statistically significant, was less marked than when the surgery was performed on Day 3 (Group 2, Table 1).

\section{TABLE 3}

EFFECTS OF OVARIECTOMY AND OVARIECTOMY + ADRENALECTOMY ON VIABILITY OF BLASTOCYSTS AS TESTED BY TRANSFER TO PSEUDOPREGNANT REGIPIENTS

\begin{tabular}{c|c|c|c|c|c}
\hline $\begin{array}{c}\text { Donor- } \\
\text { group }\end{array}$ & $\begin{array}{c}\text { Donor of } \\
\text { blastogysts }\end{array}$ & $\begin{array}{c}\text { Total no. of } \\
\text { blastocysts } \\
\text { transferred }\end{array}$ & $\begin{array}{c}\text { No. of } \\
\text { pseudo- } \\
\text { pregnant } \\
\text { recipients }\end{array}$ & $\begin{array}{c}\text { Total no. of } \\
\text { foetuses at } \\
\text { Day 20 of } \\
\text { pregnancy }\end{array}$ & $\begin{array}{c}\text { No. of } \\
\text { normal } \\
\text { foetuses }\end{array}$ \\
\hline 1 & Intact & 56 & 6 & $46(82)$ & $29(52)$ \\
2 & $\begin{array}{l}\text { Ovariectomized* } \\
\text { Ovariectomized } \\
\text { and } \\
\text { adrenalectomized* } \\
\text { Ovariectomized + } \\
\text { progesterone } \\
\text { (4 mg)(Day 3) }\end{array}$ & 30 & 8 & $14(50)$ & $3 i(11)$ \\
\hline
\end{tabular}

Blastocysts were transferred to recipients on Day 5 and recipients were killed on Day 20 of pregnancy. Numbers in parentheses represent percentage of blastocysts transferred.

* Ovariectomy and/or adrenalectomy performed on the morning of either Day 3 or 4 .

Adrenalectomy alone (i.e. without ovariectomy) on Day 3 of pregnancy (Group 9) had no detectable effect on the number or size of implants measured on Day 14 of pregnancy.

\section{Viability of blastocysts}

The viability of blastocysts deprived of ovarian and/or adrenal steroids for 4 days was judged by the size and number of implants after treatment with ovarian steroids (Text-fig. 1). In rats subjected to ovariectomy alone on Day 4 (Treatment-group 1), the number of implants was significantly below that in the intact control group (Treatment-group 3) but the size of the implants in the two groups was comparable (Table 2). On the other hand, rats subjected to adrenalectomy and ovariectomy (Treatment-group 2) showed significantly fewer implants $(P<0.01)$ than rats which were subjected to ovariectomy alone and they were markedly smaller $(P<0.001)$. Histologically, many implant sites in Treatment-group 2 appeared to be degenerating while those in Treatment- 
group 1 were not. These results suggest that deprivation of ovarian hormones has a significant effect on the number of blastocysts implanting when compared with the controls subjected to sham operation (Treatment-group 3) but deprivation of both ovarian and adrenal hormones has a more markedly deleterious effect on blastocyst viability.

\section{Blastocyst transfer}

Of the blastocysts from pregnant rats transferred to pseudopregnant recipients on Day $5,82 \%$ developed into foetuses when examined on Day 20 of pregnancy (Table 3), but only $52 \%$ into foetuses classified as healthy and viable. The remainder were resorbing. By comparison, $50 \%$ of the blastocysts transferred from donors ovariectomized on Day 3 or 4 developed into foetuses but only $11 \%$ into viable foetuses (Donor-group 2). The results were similar with rats subjected to both adrenalectomy and ovariectomy (Donor-group 3 ). When ovariectomized rats received progesterone (Donor-group 4), there was a marked improvement in the number of blastocysts developing into viable foetuses (Table 3 ).

\section{DISGUSSION}

The extent to which results are influenced by incomplete surgical removal of the ovaries is conjectural, though daily vaginal smears and uterine weight at autopsy provide indirect indices of the presence of residual ovarian tissue. Incomplete ovariectomy has the usual sequelae of implantation of blastocysts such as occurred in one rat from Group 4 (Table 1) or vaginal cornification with lack of uterine atrophy as observed in some rats in Groups 5 and 6 (Table 1). Since such rats were discarded, it is unlikely that the results were materially influenced by the incomplete removal of gonads.

The results obtained here indicate that removal of ovaries with no progesterone treatment for the subsequent 5 to 6 days exerts marked effects on both the number and viability of blastocysts. The number of blastocysts recovered from such rats was significantly lower than that from rats subjected to sham ovariectomy on Day 3 and killed on Day 5. Ovariectomy on Day 3 exerted more severe effects on the blastocyst yield than when this operation was delayed until the morning of Day 4 of pregnancy. Injection of progesterone into ovariectomized rats (Groups 4 and 7, Table 1) failed to restore the blastocyst yield to the level of the controls subjected to sham operation (Group 1, Table 1). This may be related to the surgical trauma associated with ovariectomy. Alternatively, progesterone alone may be unable to replace the deficiency of gonadal hormones created by ovariectomy; perhaps $20 \alpha-\mathrm{OH}$-progesterone or oestrogen may be required. In addition to diminution in the yield of blastocysts, ovariectomy also affected their viability as judged by their capacity to implant and grow into normal mature foetuses upon transfer to recipients (Donor-group 2, Table 3). Under these conditions, over $90 \%$ of the transferred blastocysts failed to grow into normal foetuses when examined on Day 20 of pregnancy. Such an effect of ovariectomy could not be detected when autopsy was performed earlier as in Exp. 2 (Table 2). Here, the number and size of implants were similar to the group which received progesterone beginning on 
the day of ovariectomy (Group 4, Table 1). Canivenc \& Laffargue (1957) and Buchanan (1969) were also unable to find any damaging effect of ovariectomy on blastocyst viability when examined after 5 days of progesterone treatment. It appears, therefore, that some effects of deprivation of progesterone do not become manifest until blastocysts are permitted to grow into mature foetuses.

The loss of blastocysts resulting from ovariectomy was further accelerated when adrenalectomy was coupled with it (Groups 2 and 6 , Table 1). The exact pathway by which the adrenal exerts this influence in the absence of ovaries remains to be delineated. However, it is unlikely to be a non-specific or permissive effect of the adrenals on the general condition of the animal but appears to be due to an accompanying deprivation of adrenal progesterone or other steroids with progestational properties (Burrows, 1949). This is substantiated by the fact that injection of progesterone into ovariectomized and adrenalectomized rats (Group 3, Table 1) restored blastocyst yield to a level found in rats subjected to ovariectomy alone (Group 1, Table 1).

Secretion of progesterone by the adrenals has been demonstrated in several species such as the pig and dog (Balfour, Comline \& Short, 1957; Short, 1960; Heap, Holzbauer \& Newport, 1966), human (Little \& Billiar, 1969) and guinea-pig (Feder \& Ruf, 1969). Progesterone is also present in the peripheral plasma of ovariectomized rats (Feder, Resko \& Goy, 1968; Feder \& Ruf, 1969) but becomes undetectable following their adrenalectomy (Resko, 1969). Besides progesterone, the adrenals secrete a vast array of other steroids, several of which are known to have progestational properties (Burrows, 1949). Thus, the influence of adrenalectomy on blastocyst yield is not surprising. It seems to become critical only in the absence of ovaries, however, since simple adrenalectomy of pregnant rats failed to exert comparable effects (Group 9, Table 1).

Adrenalectomy also seems to affect the viability of blastocysts for fewer implanted when treatment with progesterone and oestrogen was withheld for 4 days after adrenalectomy and ovariectomy (Treatment-group 2, Table 2). Thus, unlike the effect of ovariectomy which did not become manifest until late in pregnancy, the effect of adrenalectomy superimposed on ovariectomy became evident at an early stage of pregnancy. When blastocysts were transferred from such rats to recipients, again more than $90 \%$ failed to develop into viable foetuses, this proportion not being materially different from that when donor rats were subjected to ovariectomy alone (Donor-group 2, Table 3). This lack of difference may have been due to the limited number of recipients used.

Persistence of blastocysts in a viable state in the absence of ovaries has given rise to the view that progesterone is not required for their maintenance (Weitlauf \& Greenwald, 1968; Buchanan, 1969). Other investigators have reported that implantation of blastocysts can proceed in the absence of ovaries in the armadillo (Buchanan, Enders \& Talmage, 1956) and guinea-pig (Deanesly, 1960).

This, however, does not mean that these events are independent of progesterone. Our results raise the question about the participation of steroids of adrenal origin in these processes in the absence of ovaries. The conclusion that the survival or intrauterine implantation of the blastocyst is independent of 
progesterone or progestational steroids must be reserved until it has been studied in the adrenalectomized animal.

\section{ACKNOWLEDGMENTS}

\section{The author appreciates the devoted technical assistance of Miss Rosemary Chester.}

\section{REFERENCES}

Balfour, W. E., Comline, R. S. \& Short, R. V. (1957) Secretion of progesterone by the adrenal gland. Nature, Lond. $180,1480$.

BANIK, U. \& KeTchel, M. M. (1965) Hormonal induction of pseudopregnancy in rats. F. Reprod. Fert. 10, 85.

Buchanan, G. D. (1969) Blastocyst survival in ovariectomized rats. J. Reprod. Fert. 19, 279.

BuChaNAN, G. D., ENDERs, A. C. \& TALMAGE, R. V. (1956) Implantation in armadillos ovariectomized during the period of delayed implantation. F. Endocr. 14, 121.

Burrows, H. (1949) Biological actions of sex hormones, p. 533. Cambridge University Press.

Canivenc, M. \& Lafrargue, M. (1957) Survie des blastocystes de rat en l'absence d'hormones ovariennes. C.r. hebd. Séanc. Acad. Sci., Paris, 245, 1752.

Cochrane, R. L. \& Meyer, R. K. (1957) Delayed nidation in the rat induced by progesterone. Proc. Soc. exp. Biol. Med. 96, 155.

Deanesty, R. (1960) Implantation and early pregnancy in ovariectomized guinea-pigs. F. Reprod. Fert. $1,242$.

Dickmann, Z. (1968) Can the rat blastocyst survive in the absence of stimulation by the ovarian hormones? F. Endocr. 42, 605.

Enders, A. C. (1963) Delayed implantation. University of Chicago Press.

ENDERs, A. C. (1967) The uterus in delayed implantation. In: Cellular Biology of the Uterus, p. 151. Ed. R. M. Wynn. Appleton Century Crofts, New York.

Feder, H. H., Resko, J. A. \& Goy, R. W. (1968) Progesterone levels in the arterial plasma of preovulatory and ovariectomized rats. F. Endocr. 41, 563.

FEDER, H. H. \& RUP, K. B. (1969) Stimulation of progesterone release and estrous behavior by ACTH in ovariectomized rodents. Endocrinology, 84, 171.

Heap, R. B., Holzbauer, M. \& Newport, H. M. C. (1966) Adrenal secretion rates of C-19 and C-21 steroids before and after hypophysectomy in the pig and dog. 7. Endocr. 36, 159.

LABHSETWAR, A. P. (1969) Influence of progesterone on the pituitary and plasma levels of LH and FSH in the female rat. Biol. Reprod. 1, 189.

Little, B. \& Billiar, R. B. (1969) Progesterone production. In: Progress in Endocrinology, p. 871. Ed. C. Gual. Excerpta Medica Foundation, Amsterdam.

McLAREN, A. (1969) Stimulus and response during early pregnancy in the mouse. Nature, Lond. 221, 739.

Meyer, R. K. \& Cochrane, R. L. (1962) Induction of implantation in the ovariectomized progesterone-treated rat after adrenalectomy. F. Endocr. 24, 77.

Nutting, E. F. \& Meyer, R. K. (1963) Implantation delay, nidation, and embryonal survival in rats treated with ovarian hormones. In: Delayed Implantation, p. 233. Ed. A. C. Enders. University of Chicago Press.

REsko, J. A. (1969) Endocrine control of progesterone secretion in the ovariectomized rat. Science, N.Y. $164,70$.

Shaikh, A. \& Abraham, G. E. (1969) Measurement of estrogen surge during pseudopregnancy in rats by radioimmunoassay. Biol. Reprod. 1, 378.

Shelesnyak, M. C. (1960) Nidation of the fertilized ovum. Endeavour, 19, 81.

Short, R. V. (1960) The secretion of sex hormones by the adrenal gland. Biochem. Soc. Symp. 18, 59.

SmIthberG, M. \& RUNner, M. N. (1960) Retention of blastocysts in non-progestational uteri of mice. J. exp. Zool. 143, 21.

Weitlaut, H. \& GREEnwald, G. S. (1968) Survival of blastocysts in the uterus of ovariectomized mice. F. Reprod. Fert. 17, 515. 